\title{
Pengembangan model manajemen Ma'had Al-Jami'ah IAIN Surakarta
}

\author{
Hafidah \& Imam Makruf* \\ Fakultas Ilmu Tarbiyah, IAIN Surakarta, Indonesia \\ *imammakruf@gmail.com
}

\begin{abstract}
This study aims to produce a guide to the management model of Ma'had al Jami'ah that is appropriate in IAIN Surakarta. This research uses a mixed-method approach that combines quantitative and qualitative approaches. Data collected through questionnaires, interviews, observations, and documentation. The data is elaborated and validated through FGD and triangulation. The data analysis is carried out with an interactive model. The results of this study indicate that 1) all stakeholders consider the Surakarta IAIN to have the Ma'had Al-Jami'ah program because of the strategic position of the Surakarta IAIN, both geographically and ideologically; 2) Relevant programs are developed following the vision and mission of the institute, as well as the objectives of conducting education and the established competency standards of graduates; 3) The Ma'had Al-Jami'ah program is managed by a technical implementation unit under the coordination of the Vice Chancellor for Student Affairs; 4) strategies that can be taken to realize the Ma'had Al-Jami'ah management model that is relevant to IAIN Surakarta are starting from planning, organizing, mobilizing, and controlling involving the elements of higher education and Quality Assurance Institutions supported by the existence of an MOU or cooperating with nearby pesantren.
\end{abstract}

Keywords: Management, Ma'had Al-Jami'ah, Stakeholder Response

\begin{abstract}
Abstrak
Penelitian ini bertujuan untuk menghasilkan panduan model manajemen Ma'had al Jami'ah yang tepat diterapkan di IAIN Surakarta. Penelitian ini menggunakan pendekatan mixed methode yang menggabungkan antara pendekatan kuantitatif dan kualitatif. Data dikumpulkan melalui angket, wawancara, observasi, dan dokumentasi. data dielaborasi dan divalidasi melalui FGD dan triangulasi. Analisis data dilakukan dengan interactive model. Hasil penelitian ini menunjukkan bahwa 1) semua stakeholder menganggap IAIN Surakarta perlu memiliki program Ma'had AlJami'ah karena posisi strategis IAIN Surakarta, baik geografis maupun ideologis; 2) Program yang relevan dikembangkan disesuaikan dengan visi dan misi institut, serta tujuan penyelenggaraan pendidikannya dan standar kompetensi lulusan yang telah ditetapkan; 3) Program Ma'had AlJami'ah dikelola oleh unit pelaksana teknis di bawah koordinasi wakil Rektor bidang kemahasiswaan; 4) strategi yang dapat dilakukan untuk mewujudkan model manajemen Ma'had Al-Jami'ah yang relevan dengan IAIN Surakarta adalah dengan dimulai dari perencanaan, pengorganisasian, penggerakan, dan pengendalian yang melibatkan unsur pimpinan perguruan tinggi dan Lembaga Penjaminan Mutu yang didukung dengan adanya MOU atau bekerja sama dengan pesantren-pesantren sekitar.
\end{abstract}

Kata kunci: Manajemen, Ma'had Al-Jami'ah, Respons Stakeholder.

Diserahkan: 24-08-2019 Disetujui: 02-04-2020. Dipublikasikan: 03-04-2020

Kutipan: Hafidah, H., \& Makruf, I. (2020). Pengembangan model manajemen Ma'had Al-Jami'ah IAIN Surakarta. Ta'dibuna: Jurnal Pendidikan Islam, 9(1), 001-018.

doi:http://doi.org/10.32832/tadibuna.v9i1.2357 


\section{Pendahuluan}

Keberadaan Ma'had al-Jami'ah di PTKI saat ini sudah menjadi sebuah keniscayaan, sebagai tuntutan yang sangat rasional untuk mengatasi problem terkait kompetensi input yang sangat beragam. Dengan program ini, maka capaian kompetensi lulusan dapat diwujudkan secara lebih optimal. Sebagaimana dijelaskan dari hasil penelitian Nursiyam (2015, hlm. 339) bahwa sistem pembelajaran pesantren kampus cukup berpengaruh terhadap penguatan akidah dan akhlak mahasiswa IAIN Samarinda. Senada dengan itu, Nurul Abidin (2016, hlm. 210) mengkaji bahwa manajemen pesantren yang baik dapat menumbuhkan kesadaran beragama mahasiswa di pesantren mahasiswa Al Manar Universitas Muhammadiyah Ponorogo.

Dalam kenyataannya, masih banyak PTKIN yang belum memasukkan Ma'had alJami'ah dalam Ortaker (Organisasi dan Tata Kerja) Perguruan Tingginya, sehingga belum dapat mengembangkan program tersebut secara optimal karena terkait dengan kebijakan, penyiapan infrastruktur, SDM, pembiayaan, dan lain-lain. Meskipun demikian bukan berarti tidak ada solusi yang dapat dilakukan. Misalnya apa yang dikembangkan di IAIN Purwokerto, dengan bekerja sama dengan berbagai pondok pesantren sekitar kampus (sebelum memiliki asrama sendiri yang memadai), atau model program pesantren non asrama seperti yang dikembangkan di UIN Surabaya.

Ditinjau dari segi keterbukaan terhadap perubahan-perubahan yang terjadi di luar, pesantren sebagaimana dipopulerkan oleh Zamakhsyari Dhofier dapat dibagi menjadi dua, yaitu pesantren tradisional (salafi) dan pesantren modern (khalafi) (Dhofier, 2011). Pesantren salafi bersifat konservatif, sedangkan pesantren khalafi bersifat adaptif. Perbedaan tipologi tersebut tidak terlepas dari gaya kepemimpinan yang dikembangkan. Dalam hal ini Mujamil Qomar menyatakan bahwa gaya kepemimpinan yang diharapkan terwujud di pesantren mengarah pada tipe kepemimpinan yang profesional yang memberi perhatian khusus pada partisipasi orang lain dalam menentukan pengembangan pesantren (Qomar, 2007).

Jika merujuk beberapa hasil penelitian dapat diketahui bahwa model pengelolaan maupun kurikulum pesantren mahasiswa/ma'had al Jami'ah di beberapa perguruan tinggi memang beragam. Misalnya kurikulum UIN Maliki Malang mengintegrasikan program Ma'had dengan kurikulum UIN Maliki Malang, sertifikat kelulusan ta'līm al-afkar alIslāmī dan ta'lim al-Qur'ān sebagai prasyarat untuk program studi keislaman dan sebagai prasyarat ujian komprehensif (Zainiyati, 2014). Penelitian Imam Makruf tentang manajemen mutu pesantren mahasiswa intensif bahasa Arab untuk mahasiswa IAIN Surakarta, dihasilkan kesimpulan bahwa model pesantren yang dikembangkan adalah model intensif dalam satu bulan dengan menerapkan kurikulum terpadu dengan pembelajaran tematik integratif dapat meningkatkan kemampuan bahasa Arab mahasiswa secara cukup signifikan (Makruf, 2017). 
Sistem pembelajaran di pesantren memungkinkan terjadinya integrasi antar berbagai materi pelajaran dalam satu utuh. Hal ini tidak hanya terjadi di pesantren mahasiswa, tetapi juga di pondok pesantren pada umumnya, terutama yang memiliki pendidikan formal di dalamnya. Penelitian Udin Fakhruddin dan Didin Saepudin (2018, hlm. 94) menunjukkan hasil bahwa; pimpinan dan santri setuju diterapkannya integrasi sistem pembelajaran mata pelajaran umum dengan agama di pesantren. Dengan integrasi tersebut dapat mencapai tujuan dengan baik, efisien, fleksibel, luwes, mudah, dan cepat sesuai dengan karakter pesantrennya. Sedangkan dari aspek kepuasan, ditemukan adanya tingkat kepuasan yang tinggi dalam pencapaian hasil belajar, peningkatan kemampuan individu, dalam penentuan kebutuhan pembelajaran dan strategi peningkatan mutu pembelajaran.

Penelitian di IAIN Surakarta ini berupaya menghasilkan desain yang berbeda dengan ma'had al-Jami'ah yang sudah ada selama ini. Hal ini dikarenakan IAIN Surakarta sebagai salah satu PTKIN yang memiliki latar belakang historis sebagai PTKIN rujukan untuk studi lanjut para alumni MAN PK di Indonesia, sudah seharusnya terus meningkatkan mutu lulusan khususnya dalam bidang kebahasaan dan keislaman. Namun selama ini pembinaan kompetensi lulusan mahasiswa di IAIN Surakarta masih ditangani secara parsial, belum terintegrasi dan terstruktur secara sangat baik. Berbagai program standarisasi SKL yang sudah ada masih belum mampu menghasilkan output yang benar-benar punya kompetensi unggul. Salah satu contoh, program pembinaan bahasa asing oleh P2B, pembinaan SKL Ibadah dan Al-Qur'an oleh tim (ad hok), dan sertifikasi SKL TIK oleh PTIPD, masih dihadapkan pada berbagai problematika. Masalah utama untuk pembinaan bahasa asing, Al-Qur'an, dan Ibadah adalah ketiadaan asrama, sehingga menjadi kendala untuk menyelenggarakan program pembinaan secara intensif dan terintegrasi.

Upaya untuk melakukan perintisan Ma'had Al-Jami'ah di IAIN Surakarta sebenarnya sudah mulai dilakukan. Namun demikian inisiasi ini munculnya justru dari jurusan dan fakultas. Sebagai contoh, sejak tahun 2005 Program Studi PBA sudah mengembangkan Pesantren Mahasiswa Darussalam untuk pembinaan mahasiswa PBA tahun pertama. Kemudian disusul berdirinya Pesantren Tahfidz Syifaul Qur'an yang diprakarsai jurusan PAI, dan tahun ini sedang dibangun Pesantren Tahfidz yang dibiayai dari dana ZIS para dosen FITK. Di fakultas lain juga sudah memiliki pesantren mahasiswa meskipun semuanya masih harus menyewa rumah sebagai pusat kegiatannya. Program-program ini menjadi modal berharga untuk pengembangan Ma'had Al-Jami'ah di tingkat institut. Model pengelolaan Ma'had tersebut harus mampu menjadi wadah pembinaan kompetensi lulusan di tingkat institut dan menjadi garansi terhadap kualitas lulusan IAIN Surakarta sesuai profil yang ditetapkan.

Terkait dengan penyelenggaraan pesantren mahasiswa di FITK IAIN Surakarta, sudah pernah dilakukan penelitian oleh Khuriyah dan Noor Alwiyah (2016, hlm. 91) yang menghasilkan kesimpulan bahwa; model pesantren mahasiswa yang tepat 
dikembangkan di FITK IAIN Surakarta adalah model pengelolaan yang dihasilkan melalui tahapan perencanaan (planning), mengembangkan produk awal, pengujian lapangan awal, dan revisi produk akhir.

Berdasarkan berbagai pertimbangan tersebut, maka untuk pengembangan sebuah model manajemen Ma'had Al-Jami'ah yang ideal, relevan dengan situasi dan kondisi yang ada di IAIN Surakarta, dibutuhkan proses assessment yang memadai dan komprehensif. Hal ini dapat dilakukan dengan melibatkan semua stakeholder internal dan eksternal untuk mengakomodasi semua harapan dan cita-cita bersama. Proses perumusan model manajemen ma'had ini juga harus dirumuskan secara sistematis dan melalui tahapan-tahapan yang benar. Untuk itulah penelitian ini dilakukan agar menghasilkan model manajemen yang tepat diterapkan di IAIN Surakarta dengan rumusan masalahnya adalah; (1) Bagaimana respons stakeholder internal dan eksternal terhadap pengembangan model manajemen Ma'had Al-Jami'ah IAIN Surakarta?; (2) Bagaimana alternatif program yang tepat dan relevan dikembangkan pada Ma'had Al-Jami'ah IAIN Surakarta?; (3) Bagaimana model manajemen penyelenggaraan Ma'had Al-Jami'ah yang tepat dikembangkan dan dapat diterapkan di IAIN Surakarta?; dan (4) Bagaimana strategi yang dapat dilakukan untuk mewujudkan model manajemen Ma'had Al-Jami'ah yang relevan dengan IAIN Surakarta?

Penelitian ini diharapkan dapat memberikan tambahan referensi dalam bidang manajemen Lembaga Pendidikan Islam secara umum dan khususnya dalam bidang manajemen Ma'had Al-Jami'ah, dan hasil temuan penelitian ini dapat menjadi salah satu model alternatif teoritis yang dapat diuji kembali dengan penelitian lain baik yang bersifat implementatif maupun yang bersifat kajian teoritis sehingga dapat menghasilkan model yang lebih implementatif.

\section{Metode Penelitian}

Penelitian ini menggunakan pendekatan penelitian yang memadukan antara deskriptif kuantitatif dan survei dengan deskriptif kualitatif. Menurut Cresswell (2005), sebagaimana dikutip Lodico, Marguerite G. at. all, (2010, hlm. 40), sebuah penelitian dapat menggunakan pendekatan kualitatif, kuantitatif, atau menggabungkan di antara keduanya. Dalam hal ini, data kuantitatif diposisikan sebagai sumber data awal dan dianalisis dengan pendekatan deskriptif kuantitatif. Kemudian hasil analisis tersebut dilanjutkan dengan penguatan data kualitatif yang kemudian dilanjutkan dengan analisis secara kualitatif. Menurut Lodico, Marguerite G. at. all, (2010, hlm. 56), "descriptive survey research aims to describe behaviors and to gather people's perceptions, opinions, attitudes, and beliefs about a current issue in education. These descriptions are then summarized by reporting the number or percentage of persons reporting each response". Dengan demikian, dalam penelitian ini, metode survei digunakan untuk mengumpulkan data sebanyak 
mungkin dari responden terkait dengan persepsi mereka terhadap pengembangan model manajemen Ma'had Al-Jami'ah.

Penelitian ini dilaksanakan selama 4 (empat) bulan mulai dari bulan Juni - September 2018, yang terdiri atas tiga tahapan utama, yaitu tahap perencanaan, tahap pengumpulan data di lapangan, dan tahapan analisis dan pelaporan hasil penelitian. Responden dalam penelitian ini adalah stakeholder internal dan stakeholder eksternal. Stakeholder internal meliputi para pimpinan IAIN Surakarta mulai dari Rektor, Wakil Rektor, Dekan, para Wakil Dekan, ketua lembaga, ketua jurusan, dosen, karyawan, dan mahasiswa. stakeholders eksternal di antaranya para pimpinan lembaga pendidikan atau lembaga lain yang menggunakan alumni IAIN Surakarta, para pimpinan pondok pesantren, dan lainnya. Selain sebagai responden, beberapa pihak juga menjadi subyek penelitian ini untuk pendalaman data kualitatif, yaitu Wakil Dekan bidang Pembinaan Kemahasiswaan dan Ketua Jurusan di lingkungan IAIN Surakarta, serta beberapa pimpinan Madrasah dan Pesantren mitra.

Data dikumpulkan melalui angket, dokumentasi, observasi, wawancara. Angket untuk menggali informasi tentang persepsi stakeholder internal dan eksternal terhadap pengembangan model pengelolaan Ma'had Al-Jami'ah IAIN Surakarta. Observasi digunakan untuk melihat potensi sarana prasarana, proses pembinaan SKL yang sudah berjalan saat ini, dan penyelenggaraan pesantren mahasiswa yang sudah ada di masingmasing fakultas. Wawancara digunakan untuk mengumpulkan data terkait dengan arah pengembangan Ma'had Al-Jami'ah, model pengelolaan, dan program pembinaan mahasiswa yang diharapkan. Di samping teknik-teknik tersebut, peneliti juga sekaligus bertindak sebagai key instrument (Sugiyono, 2008, hlm. 251).

Proses penyebaran angket dilakukan kepada 110 responden yang terdiri atas 40 responden eksternal dan 70 responden internal. Berdasarkan hasil rekapitulasi hasil angket yang dikumpulkan, terdapat 105 responden yang mengisi dan menyerahkan kembali angket, yaitu 39 responden eksternal, dan 66 responden internal. Dari hasil angket tersebut, kemudian diolah dan ditabulasi sesuai dengan kategori data yang selanjutnya dijadikan data awal untuk didalami melalui wawancara, studi dokumentasi dan dilanjutkan dengan proses validasi dan analisis secara komprehensif.

Untuk pemeriksaan keabsahan atau validasi data digunakan teknik kecukupan referensial dan teknik triangulasi. Dalam uji validitas data dengan kecukupan referensial dibutuhkan bahan-bahan referensi yang memadai. Dalam hal ini, semua data akan dikumpulkan dan dianalisis secara terus menerus dan dilakukan pendalaman data melalui Focus Group Discussion (FGD) sampai dirasa cukup. Sedangkan untuk triangulasi, Denzin, dalam Lexy Moleong (2011, hlm. 178) membedakan empat macam triangulasi, yaitu menggunakan sumber, metode, penyidik, dan teori. Dalam penelitian ini model triangulasi yang akan dilakukan adalah menggunakan triangulasi metode. Dengan demikian 
keabsahan data yang diperoleh melalui observasi akan dibandingkan dengan hasil wawancara dan dengan dokumen-dokumen yang dapat ditemukan.

Proses validasi data dengan triangulasi data dalam kegiatan Focus Group Discussion (FGD) untuk membahas draf hasil penelitian berupa Panduan Pengembangan Model Ma'had Al-Jami'ah IAIN Surakarta. FGD dilaksanakan sebanyak dua kali, yaitu pada tanggal 28 Juli dan 11 Agustus 2018 dengan menghadirkan narasumber Wakil Rektor Bidang Kemahasiswaan dan Kerja sama IAIN Salatiga selaku penanggung jawab Ma'had Al-Jami'ah IAIN Salatiga. Sedangkan peserta pembahas dalam FGD tersebut adalah para wakil dekan bidang kemahasiswaan dan kerja sama, ketua jurusan serta para dosen di lingkungan IAIN Surakarta sebagai stakeholder internal. FGD juga dihadiri alumni, para pimpinan pondok pesantren sekitar kampus IAIN Surakarta, pimpinan madrasah mitra sebagai stakeholder eksternal.

Setelah data terkumpul, kemudian data tersebut dikaji secara lebih mendalam menggunakan dua teknik analisis. Untuk data kuantitatif digunakan teknik analisis dengan rumus persentase. Sedangkan untuk data kualitatif dilakukan analisis dengan teknik interaktif model dari Miles and Huberman (2007) terdiri atas pengumpulan data mentah, display data, reduksi data dan verifikasi/kesimpulan. Model interaktif tersebut digambarkan pada gambar 1 berikut:

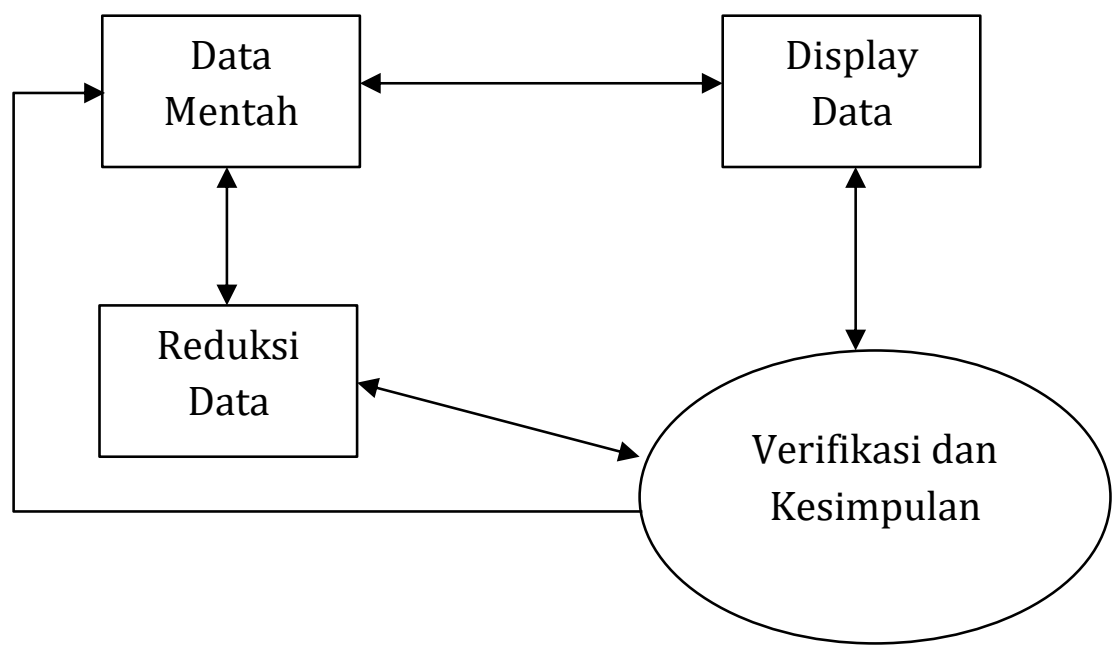

Gambar 1. Model Interaktif dari Miles dan Huberman

Proses analisis data dilakukan secara terus menerus bersamaan dengan pengumpulan data. Dalam proses analisis ini juga dilakukan dengan FGD untuk mendalami data yang telah dikumpulkan sekaligus merumuskan pengembangan model manajemen Ma'had Al-Jami'ah IAIN Surakarta. 


\section{Hasil dan Pembahasan}

\section{A. Respons stakeholder internal dan eksternal terhadap pengembangan model manajemen Ma'had Al-Jami'ah IAIN Surakarta}

Respons stakeholder yang dimaksud dalam hal ini meliputi respons tentang pentingnya keberadaan Ma'had Al-Jami'ah di kampus IAIN Surakarta dan posisi IAIN Surakarta untuk pengembangan Ma'had Al-Jami'ah baik secara geografis, ideologis, akademik maupun sosio-kultural. Data respons tentang pentingnya keberadaan Ma'had Al-Jami'ah di kampus IAIN Surakarta diperoleh melalui wawancara, sedangkan data respons tentang posisi IAIN Surakarta untuk pengembangan Ma'had A-Jami'ah diperoleh melalui angket.

Data yang diperoleh dari wawancara menunjukkan bahwa sebagian besar responden menyatakan perlunya IAIN Surakarta memiliki atau mengembangkan program Ma'had Al-Jami'ah dengan beberapa pertimbangan. Di antaranya adalah karena IAIN Surakarta memiliki posisi yang strategis baik dari segi geografis maupun ideologis. Secara strategis karena berada di persimpangan segitiga emas yang menghubungkan antara Jawa Timur, Jawa Tengah, dan DIY. Sedangkan secara strategis secara ideologis karena IAIN Surakarta berada di wilayah Solo Raya yang merupakan pusat berbagai paham keagamaan. Hal ini diperkuat dengan data hasil angket yang dikumpulkan dari stakeholder internal dan eksternal kampus. Data angket tersebut menunjukkan bahwa secara geografis yang menyatakan setuju dan sangat setuju dari stakeholder internal sebanyak 38 responden dan yang eksternal sebanyak 65 responden dari total 66 responden. Sementara itu untuk respons terhadap posisi strategis secara ideologis dari stakeholder internal juga lebih dominan menyatakan setuju dan sangat setuju. Peta responden tersebut dapat disajikan dalam tabel 1 berikut:

Tabel 1. Respons Stakeholder terhadap Posisi Strategis IAIN Surakarta

\begin{tabular}{ccc}
\hline Jawaban & Eksternal & Internal \\
\hline IAIN Surakarta strategis secara geografis & 38 & 65 \\
IAIN Surakarta strategis secara ideologis & 36 & 60 \\
\hline
\end{tabular}

Berdasarkan data-data tersebut, maka dapat dipahami bahwa program pesantren mahasiswa di IAIN Surakarta sangat penting dan sangat diperlukan. Pertimbangannya adalah input mahasiswa yang berasal dari berbagai lulusan, ada yang dari pondok pesantren, MA, bahkan SMA dan SMK yang tentukan kemampuan dan pengetahuan agama Islamnya juga beragam. Ada yang sudah menguasai pengetahuan agama Islam dengan baik, namun tidak sedikit yang belum menguasai pengetahuan agama Islam termasuk belum mampu membaca Al-Qur'an bahkan banyak pula yang tidak bisa. Di samping itu dari latar belakang pendidikannya yang sangat beragam ideologinya, dimungkinkan adanya pemahaman yang berbeda-beda yang tidak menutup kemungkinan akan terjadinya gesekan antar kelompok. Oleh karena itu perlu menjadi perhatian adanya pembinaan 
keagamaan yang mengarah pada Islam moderat, toleran, dan membentengi mahasiswa dari radikalisme.

Ma'had Al-Jami'ah bukan sekedar berfungsi sebagai pengganti tempat kos-kosan, sebagaimana halnya asrama mahasiswa di beberapa perguruan tinggi, melainkan sebagai bagian penting dari proses pendidikan yang harus dilalui oleh mahasiswa. Hal ini sebagaimana pernyataan Imam Suproyogo (Taufiqurrochman, 2010) tentang kedudukan dan fungsi Ma'had Aly UIN Maliki Malang. Menurutnya, posisi ma'had sangat strategis mengingat ma'had menempati urutan ketiga dalam arkan al-jami'ah setelah dosen dan masjid. Hal ini menandakan bahwa ma'had menjadi lembaga yang sangat urgen setelah masjid. Di ma'had ini mahasiswa diharuskan mengikuti berbagai kegiatan yang padat dengan disiplin. Sehingga mahasiswa di kampus perguruan tinggi Islam tidak saja mendapatkan ilmu pengetahuan, tetapi lebih dari itu, agar terbentuk watak keulamaan dan kecendekiaan sekaligus. Jadi proses pendidikan di ma'had itu mencakup learning to know, learning to do, learning to become, dan juga learning to life together.

\section{B. Program yang tepat dan relevan dikembangkan pada Ma'had Al-Jami'ah IAIN Surakarta}

Ma'had al-Jami'ah, sebagai model pesantren di perguruan tinggi, dapat disamakan dengan Ma'had 'Aly. Konsep dasarnya adalah pengembangan pendidikan di perguruan tinggi berbasis pesantren. Dalam hal ini, menurut Mujamil Qomar ada beberapa kebijakan yang perlu memperoleh perhatian di perguruan tinggi. Di antaranya adalah; mempertegas orientasi kelembagaan pada orientasi akademik yang mandiri dan mendalam; memperkuat penguasaan epistemologi dan metodologi; menggali Mutiara pengetahuan keislaman klasik; mempertahankan tradisi penguasaan dan telaah kitab-kitab Islam klasik di kalangan dosen dan mahasiswa, dan membentuk lembaga yang berfungsi memberikan pemecahan masalah keagamaan kepada masyarakat sekitar, semacam bahts al-masa'il sehingga memiliki kontribusi yang nyata bagi kepentingan yang lebih luas (Qomar, 2007).

Dari hasil penelitian yang dilakukan, ada beberapa pendapat responden yang berbeda dalam menanggapi hal ini. Sebagian responden menyatakan program yang sebaiknya dikembangkan adalah pembinaan baca dan tulis al-Qur'an (BTA), ada juga yang berpendapat sebaiknya penguatan bahasa asing, ada yang berpendapat Ma'had Al-Jami'ah harus melakukan pembentukan karakter mahasiswa yang islami dan pembinaan akhlakul karimah. Berbagai pendapat itu didasarkan pada berbagai alasan ataupun orientasi masing-masing. Menurut Zainul Abas, pimpinan pesantren mahasiswa Darussalam Kartasura bahwa program yang sebaiknya dikembangkan pada Ma'had Al-Jami'ah fokus pada latar belakang ide Ma'had Al-Jami'ah ini dimunculkan. Sehingga program yang seharusnya dikembangkan adalah Baca tulis al-Quran, praktik ibadah dan pengetahuan keagamaan, pembiasaan akhlakul karimah, dan bisa juga dikembangkan program 
pengembangan bahasa asing (wawancara, 20 Juli 2018). Hal yang sama juga dikemukakan oleh Ni'am Zuhri, S. Ag, kepala MI Al-Islam Kartasura. Menurutnya kurikulum yang dikembangkan semua dikembalikan pada visi dan misi atau tujuan didirikannya pesantren kampus, jadi lebih mengarah pada lulus kompetensi bahasa dan juga kompetensi ibadah dan yang tidak boleh dilupakan adalah akhlakul karimah (wawancara, 18 Juli 2018). Dua pendapat ini merupakan representasi dari pendapat stakeholder eksternal, karena sebagian besar dari mereka menyatakan bahwa program yang seharusnya dikembangkan adalah Baca tulis al-Quran, praktik ibadah dan pengetahuan keagamaan, pembiasaan akhlakul karimah,

Sementara responden dari stakeholder internal berpendapat beda-beda. Salah seorang dosen mengatakan program yang dikembangkan pada Ma'had Al-Jami'ah itu pembinaan al-Qur'an dan amalan ibadah harian (Bisri: wawancara, 18 Juli 2018). Responden lain, yaitu dari lembaga penjaminan mutu (LPM) IAIN Surakarta mengatakan bahwa program yang dikembangkan pada Ma'had Al-Jami'ah mestinya merujuk pada visi dan misi IAIN Surakarta dan standar kompetensi lulusan (SKL) yang telah ditetapkan sehingga Ma'had Al-jami'ah nantinya bisa mendukung pencapaian kompetensi tersebut (Fetty Ernawati, wawancara, 23 Juli 2018).

Sedangkan menurut pengelola Pusat Pengembangan Bahasa (P2B) bahwa program yang perlu dikembangkan pada Ma'had Al-Jami'ah adalah penguatan bahasa asing, bahasa Arab dan Inggris. Alasannya untuk gol internasional. Di samping perlu juga program baca dan tulis Al-Qur'an (BTA). Ada juga yang berpendapat, program yang seharusnya dikembangkan tahmid Al-Quran, bahasa Arab dan Inggris, dan public speaking. Namun demikian ada program sama yang diajukan oleh mayoritas responden, yaitu pembinaan baca tulis Al-Qur'an (BTA) dan pembinaan ibadah sehari-hari, serta pembinaan akhlak al-karimah. Para stakeholder mengharapkan adanya pembinaan secara maksimal pada materi-materi keagamaan dan bahasa asing. Materi-materi tersebut dipandang sebagai kompetensi mahasiswa sebagai calon-calon sarjana yang dihasilkan dari lembaga pendidikan tinggi keagamaan Islam.

Temuan-temuan tersebut cukup menarik karena fokus utama materi yang direkomendasikan dari para responden adalah pembinaan baca tulis Al-Qur'an dan pembinaan ibadah. Berikutnya adalah pembinaan akhlakul karimah. Jika melihat pada pendapat Chabib Thoha (2001, hlm. 87), bahwa ada nilai-nilai fundamental dari pendidikan pesantren yang selama ini jarang dipandang oleh kalangan yang menganggap dirinya modern, di antaranya: (1) komitmen untuk tafaqquh fi ad-Diin, yaitu nilai-nilai untuk teguh terhadap konsep dan ajaran agama; (2) pendidikan sepanjang waktu (full day school); (3) pendidikan integratif dengan mengolaborasikan pendidikan formal, informal dan non formal; (4) pendidikan seutuhnya, teks dan kontekstual atau teoritis dan praktis; 
(5) adanya keragaman, kebebasan, kemandirian dan tanggung jawab; (6) dalam pesantren diajarkan bagaimana hidup bermasyarakat.

Terkait dengan pembinaan akhlakul karimah ini, ada sebuah penelitian yang dilakukan oleh Ahmad Musadad dan Khoirun Nasik (2017, hlm. 135) di Pesantren Mahasiswa Universitas Trunojoyo Madura yang menghasilkan kesimpulan dua kesimpulan, yaitu; Pertama, dari kegiatan sehari hari, ada 3 (tiga) karakter utama yang ditekankan di pesantren mahasiswa, yaitu karakter tertib, santun dan peduli. Pola pendidikan karakter sudah berjalan secara efektif, tetapi masih dibutuhkan inovasi dan metode yang lebih kreatif supaya nilai-nilai tersebut lebih up to date sesuai perkembangan zaman dengan tanpa meninggalkan substansi pembentukan karakter yang dikehendaki. Kedua, pola pengajaran dan pendidikan pondok pesantren memberikan peran yang efektif terhadap pembentukan karakter tertib, santun dan peduli pada mahasiswa.

Hasil penelitian lain yang juga hampir sama dilakukan oleh Rahmatullah dan Akhmad Said (2019, hlm. 39) pada Pesantren Mahasiswa Al-Hikam Malang. Penelitian ini menyatakan bahwa pendidikan karakter di pondok pesantren tersebut diselenggarakan secara terintegrasi antara tiga komponen utama pesantren, yaitu kepengasuhan, dirasah, dan kesantrian yang ditambah dengan empat lainnya yaitu adanya tradisi pesantren, jiwa pesantren, kedisiplinan, dan struktur organisasi/manajemen. Model ini dianggap dapat menjadi rujukan dalam peningkatan mutu pendidikan karakter di Indonesia.

Proses pembinaan karakter yang lebih khas dilakukan di Pesantren Mahasiswa yang dikembangkan di IAIN Purwokerto, yaitu pembinaan kerukunan umat beragama. Hal ini sebagaimana penelitian Moh. Roqib (2017, hlm. 312) tentang diseminasi kerukunan umat beragama model pesantren mahasiswa. Hasil riset tersebut bahwa proses diseminasi kerukunan umat beragama yang dilakukan menggunakan langkah akademik sekaligus praktikum di laboratorium hidup. Proses diseminasi akademik dilakukan dengan kajian kitab kuning yang khas pesantren, seminar atau dialog yang melibatkan para cendekiawan muslim dan non-muslim, serta melalu kajian-kajian teori yang dilakukan di kelas atau di ruangan. Selain secara teori, pembinaan melalui laboratorium hidup berupa pelatihan life skill dan bekerja sama pengabdian masyarakat yang melibatkan mahasiswa dan para pemuda lintas iman. Program ini rutin dilakukan sehingga proses pembiasaan akan terjadi dan hasilnya maksimal.

Ada hal yang mendasar dalam mendukung pendidikan karakter di pondok pesantren. Sistem asrama yang mewajibkan semua santrinya tinggal di dalam pesantren selama 24 jam memungkinkan adanya program pembinaan yang berkesinambungan dan terawasi secara maksimal. Di samping itu adanya faktor keteladanan yang diberikan oleh para pengasuh dan pimpinan pondok pesantren akan turut menjadikan proses pendidikan semakin efektif. Hal ini tentu saja tidak hanya berlaku untuk pembelajaran karakter, tetapi juga untuk pembelajaran baca tulis Al-Qur'an dan praktik peribadahan sehari-hari. 
Untuk proses pembelajaran secara umum, dapat diterapkan pendekatan andragogi atau pembelajaran orang dewasa. Dalam hal ini banyak pilihan metode yang dapat digunakan. Misalnya seperti hasil penelitian Zainuddin (2016, hlm. 129) tentang implementasi andragogi di Pondok Pesantren Al Hikam Malang menghasilkan kesimpulan bahwa metode andragogi yang diterapkan yaitu, metode diskusi, metode simulasi, metode curah pendapat (brainstorming), dan metode individual. Untuk evaluasi andragogi dilakukan dengan secara individual dan kolektif. Prinsip andragogi yang diterapkan adalah amaliah agama, prestasi ilmiah, dan kesiapan hidup. Adapun model andragogi yang diterapkan adalah model muhadhoroh, ansos, dan ambak.

\section{Model manajemen penyelenggaraan Ma'had Al-Jami'ah yang tepat dikem- bangkan dan diterapkan di IAIN Surakarta}

Pesantren mahasiswa, jika merujuk klasifikasi Departemen Agama (2003) dan juga Mujamil Qomar tersebut, masuk kategori pondok pesantren kombinasi antara model salafiyah dan model modern. M. Sulthon Masyhud dan Khusnuridho (2005) memasukkan pesantren mahasiswa ini pada klasifikasi pondok pesantren dilihat dari jenis santrinya. Dengan model tersebut maka proses pembelajaran masih menggabungkan antara metode tradisional dan modern seperti sorogan, bandongan/wetonan, hafalan, dan metode pembelajaran aktif dengan memperbanyak praktik. Untuk membentuk santri yang tidak hanya memiliki jiwa spiritual tetapi juga intelektual, maka Al-Turāś sebagai landasan keilmuan pesantren sudah semestinya tetap menjadi bingkai dalam merumuskan Islam pesantren dalam konteks kekinian. Hal ini berarti kontekstualisasi nilai-nilai tradisi dalam realitas pendidikan pesantren menjadi sebuah keniscayaan (A'la, 2006).

Dari hasil kajikan yang dilakukan, model manajemen penyelenggaraan Ma'had Al-Jami'ah yang tepat dikembangkan di IAIN Surakarta menurut para stakeholders tercermin dari pendapat dan pernyataan mereka, baik melalui wawancara maupun kuesioner/angket. Di antara responden mengatakan alangkah baiknya jika pesantren kampus/mahasiswa ini dikembangkan dengan bekerja sama dengan pesantren-pesantren di sekitarnya namun program yang ditawarkan disesuaikan dengan visi-misi kampus. Adapun model pesantren yang dikembangkan adalah model pesantren modern dan juga tradisional, karena melihat tujuan didirikannya adalah untuk penguasaan bahasa dan juga baca tulis Al-Quran, mungkin dalam sistem pengajaran bahasa bisa meniru pesantren modern dan pengajaran al-Quran bisa meniru pesantren tradisional (Lukman Abdul Azis, wawancara, 18 Juli 2018).

Berbeda dengan pendapat di atas, ustadzah Tasliah (musyrifah asrama putri MAN PK Surakarta) mengatakan jika IAIN Surakarta ingin memiliki ma'had haruslah dikelola oleh kampus sendiri, seperti ma'had kampus lain seperti di UIN Malang. Hal senada juga disampaikan oleh responden lain, baik dari stakeholder internal maupun eksternal. Tentu stakeholder internal memahami kondisi sarana prasarana dan kemampuan IAIN 
Surakarta untuk menyelenggarakan Ma'had Al-Jami'ah. Dari wawancara dengan beberapa orang di internal kampus dari unsur dosen, pimpinan lembaga di lingkungan IAIN Surakarta, mereka mengatakan jika mampu sebaiknya IAIN Surakarta dapat menyelenggarakan Ma'had Al-Jami'ah secara mandiri termasuk memiliki asrama bagi mahasiswa yang menjadi santri di ma'had tersebut. Sementara itu, dari hasil angket dapat dijelaskan pada tabel 2 berikut:

Tabel 2. Respons Stakeholder terhadap Ma'had Al-Jami'ah

\begin{tabular}{lcc}
\multicolumn{1}{c}{ JAWABAN } & EKSTERNAL & INTERNAL \\
\hline Pondok Pesantren mandiri & 28 & 47 \\
Bekerja sama dengan pondok pesantren & 7 & 7 \\
Program pembinaan intensif di kampus & 4 & 8 \\
Lainnya & 0 & 2 \\
\hline
\end{tabular}

Tabel tersebut menegaskan bahwa pola pembinaan keagamaan mahasiswa yang seharusnya diterapkan di IAIN Surakarta ke depan adalah mandiri. Untuk pengembangan ke depan, sudah sangat urgen untuk mengembangkan model Ma'had Al-Jami'ah secara mandiri. Ketika IAIN Surakarta menyelenggarakan Ma'had Al-Jami'ah secara mandiri, maka harus ada unit yang secara khusus mengelola program itu dan memiliki payung hukum dalam struktur organisasi IAIN Surakarta.

Dalam kajian literatur, Ma'had Al-Jami'ah bukan sekedar berfungsi sebagai pengganti tempat kos-kosan, sebagaimana asrama mahasiswa di beberapa perguruan tinggi, melainkan sebagai bagian penting dari proses pendidikan yang harus dilalui oleh mahasiswa. Menurut Imam Suprayogo (2011, hlm. 45), perguruan tinggi dan pesantren sebenarnya memiliki akar budaya yang sama, yaitu sebagai lembaga pendidikan, hanya berbeda dalam lingkungannya. Jika perguruan tinggi dan pesantren dapat diintegrasikan dalam konteks yang integral, maka model atau sistem pendidikannya akan menjadi alternatif pengembangan pendidikan tinggi di Indonesia. Imam Suproyogo (Taufiqurrochman, 2010, hlm. 186) juga menyatakan tentang kedudukan dan fungsi Ma'had Aly UIN Maliki Malang. Menurutnya, posisi ma'had sangat strategis mengingat ma'had menempati urutan ketiga dalam arkan al-jami'ah setelah dosen dan masjid. Hal ini menandakan bahwa ma'had menjadi lembaga yang sangat urgen setelah masjid.

Keberadaan Ma'had Al-Jami'ah sebagai pusat pembelajaran keislaman di kampus sangat penting dan ideal. Namun demikian bukanlah hal yang mudah untuk mewujudkannya. Ada banyak keunggulan pesantren mandiri dengan pesantren kerja sama atau kemitraan. Dengan pengelolaan mandiri, kampus dapat membuat desain manajemennya secara lebih leluasa, tanpa harus melakukan penyesuaian dengan kebijakan dan karakter dari masing-masing pesantren mitranya. Pada tahun 2017 IAIN Surakarta juga sudah pernah mengembangkan pembinaan SKL Ibadah bekerja sama dengan beberapa pondok pesantren di sekitar kampus. Hal hasilnya masih belum maksimal karena adanya berbagai 
kendala, termasuk di dalamnya adalah sistem pengelolaan yang tidak dapat disamakan antara satu pondok pesantren dengan yang lain. Bahkan, proses pembinaan cenderung diserahkan pada masing-masing pondok pesantren. Dengan demikian belum adanya standarisasi yang sama antara satu pesantren dengan yang lain karena status programnya juga masih bersifat tentatif, bahkan para santrinya juga tidak tinggal di dalam pesantren tersebut (santri kalong).

Dalam hal ini, ada penelitian cukup menarik dari Mokhamad Endri Julianto (2016, hlm. 27) yang mengkaji tentang kepemimpinan spiritual pada pesantren mahasiswa di Malang. Penelitian tersebut menyimpulkan bahwa pesantren mahasiswa memiliki tipologi dipimpin oleh seorang mudir, wakil mudir, bendahara, dan beberapa kabid (Kepala Bidang). Spiritualitas kepemimpinan pesantren pada majelis pengasuh dapat mempengaruhi para santri dengan memotivasi agar memiliki semangat yang tangguh pada santrinya, menciptakan atmosfer organisasi yang kondusif, memberikan arahan pada visi-misi dan tujuan organisasi. Dari aspek tipologinya, pemimpin pesantren cenderung menerapkan kepemimpinan kolegial-partisipatif-demokratis-religio spiritual. Tugas dan fungsi dari kepemimpinan spiritual adalah pada proses pengambilan keputusan, pengendalian konflik dan juga pada pembangunan tim.

Dengan statusnya sebagai pesantren mahasiswa yang merupakan bagian tidak terpisahkan dari struktur organisasi kampus, maka manajemen di Ma'had al-Jami'ah tentu saja harus terintegrasi dengan manajemen kampus secara keseluruhan. Santri yang ditempatkan di pesantren sesungguhnya adalah mahasiswa IAIN Surakarta, sehingga kurikulum dan penyelenggaraan pembelajarannya terintegrasi dengan kurikulum IAIN Surakarta. Fokus utamanya adalah memberikan pembinaan kompetensi dasar sebagaimana yang telah dijelaskan di atas, yaitu bidang Bahasa Asing (Arab dan Inggris), Baca Tulis AlQur'an, praktik ibadah, dan pembinaan akhlakul karimah atau keislaman secara umum.

\section{Strategi untuk mewujudkan model manajemen Ma'had Al-Jami'ah yang relevan dengan IAIN Surakarta}

Menurut Taufiqurrochman, strategi yang diperlukan dalam implementasi manajemen Ma'had Al-Jami'ah pertama adalah upaya membangun kultur ma'had itu sendiri dan membangun pemahaman yang sama seluruh civitas akademik akan pentingnya ma'had. Kemudian menyiapkan sarana prasarana fisik berserta kelengkapannya, menyusun kurikulum dan kegiatan pembelajaran. Selain itu, diperlukan sosialisasi kepada mahasiswa dan wali mahasiswa dan menggali respons mereka tentang keberadaan Ma'had al-Jami'ah dan program pendidikannya. Dalam hal ini bisa dilakukan melalui pertemuan antara pimpinan perguruan tinggi di semua levelnya dengan seluruh wali mahasiswa (Taufiqurrochman, 2010).

IAIN Surakarta tentunya dapat melakukan berbagai langkah untuk mewujudkan model manajemen Ma'had Al-Jami'ah yang relevan dengan kondisi IAIN Surakarta tanpa 
mengabaikan idealisme. Hal ini dapat dimulai dengan merumuskan sistem rekrutmen SDM pengelola dan kualifikasinya, sistem pengelolaan atau pembinaan mahasiswa/ santri, sampai melakukan MOU atau bekerja sama dengan pesantren-pesantren sekitar. Ini yang dikatakan oleh beberapa responden. Misalnya, menurut H. M. Mahbub, pimpinan pondok pesantren Al-Fattah Kartasura bahwa kampus mesti menentukan kriteria dan sistem rekrutmen calon-calon pengasuh/Pembina Ma'had Al-Jami'ah. Tentu yang memiliki kompetensi dalam membaca Al-Qur'an, dan menguasai pengetahuan tentang keislaman khususnya ibadah mahdhoh, serta memiliki kemampuan berbahasa Arab dan bahasa Inggris aktif. Ini bisa diambilkan ataupun diseleksi dari para pengajar di pesantrenpesantren sekitar kampus (wawancara, 17 Juli 2018). Responden lain berpendapat terkait dengan manajemen SDM Ma'had Al-Jami'ah, bahwa direktur yang dipilih tentu harus yang memiliki kompetensi dalam bahasa asing dan memiliki pengetahuan serta pengalaman tentang manajerial kepesantrenan. Karena mengurusi pesantren memang membutuhkan pengalaman tersendiri. Sedang Pembina asrama bisa direkrut dari lulusan program tersebut di bawah koordinasi seorang koordinator musyrik/pembina. Pembina bisa di bagi-bagi menjadi pembina kamar yang mengatur akhlak dan peribadahan keseharian mahasantri, pembina bahasa yang mengawasi penggunaan bahasa mahasantri di pesantren (Abdul Ghofur: wawancara, 20 Juli 2018).

Adapun sistem pengelolaan mahasiswa menurut salah seorang responden dapat dilakukan dengan mewajibkan mahasiswa baru semester awal mengikuti program ini. Semua mahasiswa yang telah mendaftar dan diterima di IAIN Surakarta berarti ia juga telah terdaftar di Ma'had Al-Jami'ah. Setelah masuk nanti mungkin bisa diadakan placement test untuk pengelompokan mahasiswa sesuai kemampuannya. Untuk pembinaan dan pengembangan mungkin setiap kelompok didampingi oleh satu musyrik untuk membimbing dan mengontrol aktivitas mahasiswa di Ma'had Al-Jami'ah. Mungkin di Ma'had Al-Jami'ah juga akan diberikan program ekstra seperti qira', muhadharah, englsih club dan Arabic club (wawancara dengan DR. Zainul Abas, M. Ag, 20 Juli 2018).

Dari kajian hasil penelitian ini, setidaknya peneliti dapat merekomendasikan beberapa tahapan yang harus ditempuh IAIN Surakarta untuk mengembangkan manajemen ma'had al-Jami'ah yang baik. Dengan menggunakan teorinya Terry yang merumuskan fungsi manajemen meliputi 4 (empat) tahapan pokok, yaitu planning, organizing, actuating, dan controlling (Terry \& Rue, 1992, hlm. 9). Untuk itu dalam pengembangan manajemen ma'had al-Jami'ah ini perlu juga melakukan empat hal pokok tersebut.

Pertama, pada tahapan planning, perlu dilakukan pemetaan segala potensi yang dimiliki kampus baik internal maupun eksternal yang dirumuskan dalam sebuah analisis secara sistematis. Misalnya, kampus dapat menggunakan analisis SWOT untuk menentukan langkah-langkah berikutnya yang lebih tepat ditempuh. Fokus dari SWOT ini adalah analisis SDM, sumber daya infrastruktur dan sarana prasarana yang dilanjutkan 
dengan pembahasan perencanaan strategis yang dituangkan dalam perencanaan pengembangan kampus (Rencana Induk Pengembangan dan Rencana Strategis). Selain itu juga dilakukan proses penyiapan berbagai dokumen kebijakan dan regulasi terkait dengan sistem tata kelola, SDM, sarana prasarana, kurikulum, bahan ajar, sumber belajar, sistem pembelajaran dan pembinaan, keuangan, dan penjaminan mutunya.

Kedua, proses organizing yang dapat dilakukan dengan mengoptimalkan segala potensi yang ada untuk menciptakan tim kerja yang solid. Tugas pimpinan perguruan tinggi adalah membentuk tim pengelola ma'had dan seluruh komponen yang dibutuhkan dengan melengkapi tugas pokok dan fungsinya masing-masing sehingga roda organisasi berjalan secara baik. Struktur organisasi ma'had adalah di bawah langsung Wakil Rektor III bidang Kemahasiswaan dan Kerja sama, kemudian dipimpin oleh seorang Direktur Ma'had dibantu oleh sekretaris, bendahara, dan divisi-divisi sesuai kebutuhan. Struktur organisasi ini menyatu dengan struktur kepemimpinan IAIN Surakarta karena menjadi Lembaga Struktural. Dengan demikian sistem kerjanya tidak dapat secara otonom penuh sebagaimana pondok pesantren pada umumnya, bahkan harus memiliki integrasi manajemen antara perguruan tinggi dengan ma'had al-Jami'ah. Model integrasi ini juga diterapkan di UIN Maliki Malang. Hasil penelitian Irma Suryani Siregar (2016, hlm. 26) menunjukkan bahwa pola integrasi kampus dan pesantren di UIN Malang adalah dengan penerapan integrasi antara ilmu dan Islam dengan model diadik simbiosis mutualisme. Pola ini mengaitkan antara materi dengan kajian keislaman, mengaitkan kajian keislaman dengan keilmuan mahasiswa serta mengintegrasikannya dengan objek kajian.

Ketiga, proses actuating yang dilaksanakan untuk mengimplementasi kebijakan dan program kerja yang sudah dirumuskan secara optimal dengan komitmen yang tinggi dari semua stakeholder kampus. Proses ini adalah upaya untuk menggerakkan semua pihak sesuai dengan tugas masing-masing dan saling menguatkan satu dengan lainnya. Dengan pola manajemen yang terintegrasi antara kampus dengan ma'had al-Jami'ah, maka proses penggerakan sumber daya untuk mendukung penyelenggaraan program-program pesantren akan lebih mudah. Integrasi kurikulum antara kampus dengan ma'had juga akan menjadikan program berjalan lebih efektif dan efisien. Hal ini berbeda dengan penyelenggaraan ma'had al-Jami'ah yang model kerja sama atau kemitraan dengan pesantren di sekitar kampus.

Keempat, proses controlling yang diwujudkan dengan adanya mekanisme monitoring dan evaluasi secara berkelanjutan. Proses ini dilaksanakan melibatkan Lembaga Penjaminan Mutu perguruan tinggi yang melakukan assessment terhadap proses dan hasil dari pembelajaran atau pembinaan yang dilaksanakan di ma'had secara periodik minimal satu semester sekali. Proses evaluasi juga dapat dilaksanakan secara terintegrasi antara program perkuliahan di kampus dengan program pembelajaran di ma'had. Hal ini misalnya dilaksanakan pada materi Bahasa Arab dan Inggris dan Baca Tulis Al-Qur'an. Dengan 
demikian penyelenggaraan SKL Al-Qur'an dan Ibadah dapat dilaksanakan di pesantren tanpa dibutuhkan lagi unit khusus yang menanganinya.

Di samping keempat tahapan pokok dalam sistem manajemen tersebut, ma'had alJamiah juga perlu menjalin kerja sama kemitraan dengan berbagai pondok pesantren yang ada di wilayah Kartasura dan sekitarnya. Hal ini untuk memberikan penguatan secara kelembagaan dan perluasan area praktikum mahasiswa sekaligus dapat menjadi alternatif tindak lanjut setelah mereka selesai mengikuti program ma'had al-Jami'ah. Kerja sama ini tetap penting dilakukan dan diperluas apalagi dengan pondok pesantren yang memilik lembaga pendidikan formal setingkat SMA/MA untuk memotivasi para lulusannya untuk masuk dan melanjutkan studi di IAIN Surakarta.

\section{Kesimpulan}

Berdasarkan hasil penelitian yang telah dilakukan, maka dapat disimpulkan bahwa; Pertama, stakeholders internal (pimpinan, dosen, dan tenaga kependidikan) IAIN Surakarta maupun stakeholders eksternal berpendapat bahwa IAIN Surakarta perlu, bahkan beberapa mengatakan sangat perlu memiliki program Ma'had Al-Jami'ah karena letak strategis IAIN Surakarta, baik secara geografis maupun ideologis, serta dikarenakan input mahasiswa yang beragam kemampuan keagamaannya. Kedua, program yang relevan dikembangkan pada Ma'had Al-Jami'ah IAIN Surakarta disesuaikan dengan visi dan misi institusi, serta tujuan penyelenggaraan pendidikannya dan standar kompetensi lulusan yang telah ditetapkan. Sehingga program Ma'had Al-jami'ah tersebut dapat membantu mahasiswa (santri) mencapai standar kompetensi lulusan tersebut. Maka programnya adalah pembinaan baca dan tulis Al-Qur'an (BTA), pembinaan keislaman (akidah, fikih, akhlak), pembinaan bahasa Arab dan Inggris. Ketiga, manajemen penyelenggaraan Ma'had Al-jami'ah yang dapat dikembangkan, dari aspek unit yang menangani adalah unit pelaksana teknis di bawah koordinasi wakil rektor bidang kemahasiswaan yang diberi tanggung jawab untuk menangani pembinaan mahasiswa dan pengembangan kompetensi mahasiswa. Dalam merealisasikan program ini melibatkan para dosen/tenaga pendidik, staf/tenaga kependidikan, dan alumni sebagai pengelola Ma'had Al-Jami'ah. Keberadaan alumni ini diharapkan dapat memberikan motivasi tersendiri kepada para mahasiswa untuk dapat mencapai kompetensi yang diharapkan dan sudah dibuktikan oleh senior-seniornya tersebut. Selain alumni pelaksanaan program ini juga melibatkan mahasiswa yang biasanya didesain dengan pola tutorial atau mentoring. Dengan pola ini biasanya membutuhkan tenaga atau SDM yang lebih banyak untuk mendampingi kelompok-kelompok kecil. Di samping itu program ma'had bisa menjadi media praktikum mahasiswa yang lebih senior guna memperkuat kompetensi mereka dalam bidang keagamaan dan bahasa. Keempat, strategi yang dapat dilakukan untuk mewujudkan model manajemen Ma'had Al-Jami'ah yang relevan dengan IAIN Surakarta adalah dengan dimulai dari perencanaan, pengorganisasian, penggerakan, dan 
pengendalian yang melibatkan unsur pimpinan perguruan tinggi dan Lembaga Penjaminan Mutu yang didukung dengan adanya MOU atau bekerja sama dengan pesantrenpesantren sekitar.

\section{Daftar Pustaka}

Abidin, N. (2016). Manajemen Pesantren dalam Menumbuhkan Kesadaran Beragama Mahasiswa: Studi di Pesantren Mahasiswa Al Manar Universitas Muhammadiyah Ponorogo. Al-Idarah, Jurnal Kependidikan Islam, 6(1).

Akhmad Said, R. (2019). Implementasi Pendidikan Karakter Islam di Era Milenial pada Pondok Pesantren Mahasiswa. Ta'limuna, 9(02), 39-55.

A'la, A. (2006). Pembaruan Pesantren. Pustaka Pesantren.

Chabib, T. (2001). Teknik Evaluasi Pendidikan. PT." Raja Grafindo Persada.

Dhofier, Z. (2011). Tradisi Pesantren; Studi pandangan Hidup Kyai dan Visinya mengenai Masa Depan Indonesia. LP3ES.

Fakhruddin, U., \& Saepudin, D. (2018). Integrasi Dalam Sistem Pembelajaran di Pesantren. Ta'dibuna; Jurnal Pendidikan Islam, 7(mor 1), 94-113.

Julianto, M. E. (2016). Kepemimpinan Spiritual pada Pesantren Mahasiswa (Studi Multisitus pada Pesantren Mahasiswa Ulul Albab, Ulul Yaqin, dan Ulul Hikam Malang). Jurnal MPI, 1, 27-43.

Khuriyah, \& Alwiyah, N. (2016). Model Pengelolaan Pesantren Mahasiswa Fakultas Ilmu Tarbiyah dan Keguruan IAIN Surakarta. At-Tarbawi, 1(1).

Lodico, M. G. (2010). Methods in educational research: From theory to practice (2nd ed.). John Wiley \& Sons, Inc.

Makruf, I. (2017). Manajemen Mutu Pesantren Mahasiswa Intensif Bahasa Arab Untuk Mahasiswa IAIN Surakarta. Proceedings International Conference on Indonesian Islam, Education, and Science: The Prospects and Challenges in The East and The West, 90-96.

Miles, M. B., \& Huberman, A. M. (2007). Analisis Data Kualitatif. UI Press.

Moleong, L. J. (2011). Metodologi Penelitian Kualitatif. Remaja Rosda Karya.

Musadad, A., \& Nasik, K. (2017). Peran Pesantren Mahasiswa dalam Pembentukan Karakter Tertib, Santun, dan Peduli pada Mahasiswa Universitas Trunojoyo Madura (dan, Penerj.). Jurnal Pamator, 10 (mor 2), 135-145.

Nursiyam. (2015). Pengaruh Sistem Pembelajaran Pesantren Kampus Terhadap Penguatan Akidah Dan Akhlak Mahasiswa IAIN Samarinda. Syamil, 3(2).

Qomar, M. (2007). Manajemen Pendidikan Islam. Penerbit Erlangga.

Roqib, M. (2017). Diseminasi Kerukunan Umat Beragama Model Pesantren Mahasiswa di Purwokerto. Ibda'; Jurnal Kebudayaan Islam, 15(mor 2), 312-324.

Siregar, I. S. (2016). Integrasi Kampus dan Pesantren di UIN Maulana Malik Ibrahim Malang. Studi Multidisipliner; Jurnal Kajian Keislaman, 3(mor 2), 26-45.

Sugiyono. (2008). Metode Penelitian Kuantitatif. Kualitatif dan R\&D.

Sulthon Masyhud, M., \& Khusnurdilo, M. (2005). Manajemen Pondok Pesantren. Diva Pustaka.

Suprayogo, I. (2011). Hubungan antara Perguruan Tinggi dan Pesantren. UIN Press.

Taufiqurrochman. (2010). Imam al-Jami'ah Narasi Indah Perjalanan Hidup \& Pemikiran 
Prof. Dr. H. Imam Suprayogo. UIN Maliki Press.

Terry, G. R., \& Rue, L. W. (1992). Dasar-dasar Manajemen. PT. Bumi Aksara.

Zainiyati, H. S. (2014). Model Kurikulum Integratif Pesantren Mahasiswa dan UIN Maliki Malang. Jurnal Studi Keislaman, 18(1).

Zainuddin. (2016). Implementasi Andragogi di Pondok Pesantren Mahasiswa Al Hikam Malang. Qalamuna: Jurnal Studi Islam, 2(1). 